\title{
Selected Reference Books of 1992
}

\section{Eileen McIlvaine}

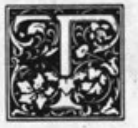

his article follows the pattern set by the semiannual series initiated by the late Constance M. Winchell more than thirty years ago and continued by Eugene Sheehy. Because the purpose of the list is to present a selection of recent scholarly and general works of interest to reference workers in university libraries, it does not pretend to be either well balanced or comprehensive. A brief roundup of new editions of standard works, new titles in series already considered reference, and pieces received on continuations orders is provided at the end of the articles. Code numbers (such as AD540 and CJ331) have been used to refer to titles in the Guide to Reference Books, 10th ed. (Chicago: American Library Assn., 1986) or to the Supplement ... Covering Materials from 1985-1990 (Chicago: 1992).

\section{PHILOSOPHY}

Encyclopedia of Ethics. Lawrence C. Becker, ed., Charlotte B. Becker, assoc. ed. Garland Reference Library of the Humanities, 925. New York: Garland, 1992. 2v. $(1,462$ p.) $\$ 150$ (ISBN 0-81530403-X). LC 91-4978.

For some time, librarians faced with students pursuing paper topics on moral and ethical issues have been able to offer two reference classics: the Encyclopedia of Philosophy (Guide BA75) and the Dictionary of the History of Ideas (Guide BA70) as starting points for background reading or beginning research. This new twovolume Encyclopedia, edited by a professor of philosophy and a librarian, will provide a welcome fresh treatment of subjects previously covered and will offer information on new issues and problems.

Addressed to "an audience of scholars and university students but fully accessible to others with a serious interest in the field," (Introd.), this Encyclopedia presents 435 signed essays by 267 contributors which range in length from 500 to 9,000 words. Entries are arranged alphabetically and cover topics such as character, forgiveness, and technology; the ethical problems of a particular discipline, such as anthropology, biology, or library and information science; ethical issues, such as academic freedom or infanticide; history and discussions of subfields in ethical and moral philosophy, such as Hindu ethics or animal rights; and biographical sketches of historical or contemporary thinkers. All articles conclude with a bibliography, some of which are surprisingly full and many of which include references to popular or nonacademic authors (e.g., Edward Abbey under "Land Ethics" and Jane Austen under "Integrity"). The extremely detailed index points to the dozens of entries, which include such aspects of broad categories as "Cooperation" or "Grace," as well as such timely and specific subjects as date rape or moral dilemmas in the novels of William Styron. In addition to the general index, the editors have thoughtfully provided an index to the $5,800 \mathrm{bib}$ liographic references.

Students will love this Encyclopedia of Ethics for its concise and clear treatment

Eileen Mcllvaine is Head of Collections and Reference in the Humanities and History Division, Columbia University Libraries, New York, New York 10027. Although it appears under a byline, this list is a project of the reference departments of Columbia University Libraries, and notes are signed with the initials of one of the following staff members: Barbara Sykes-Austin, Avery Library; James Coen, Business Library; and Mary Cargill, Olha della Cava, Beth Juhl, Robert H. Scott, Sarah Spurgin, Junko Stuveras, Butler Library. 
of some very complex social, political, and personal issues. Librarians will have trouble keeping the volumes on the shelf.

(N.B. Some of the essays in these two volumes have also appeared in a 1992 survey from Garland titled A History of Western Ethics.) - B.J.

\section{RELIGION}

Melton, J. Gordon, and Michael A. Koszegi. Religious Information Sources: A Worldwide Guide. Garland Reference Library of the Humanities, 1593. Religious Information Systems Series, 2. New York: Garland, 1992. 569p. \$75 (ISBN 0-8153-0859-0). LC 91-47697.

The compilers of this book have set for themselves the task of providing "a comprehensive guide to the many sources of information in the broad field of religion," (Introd.), with the specific aim of providing "a quick and handy reference to anyone working in a particular field" of religion. To that end, they have amassed a great variety of sources, with citations for over 2,500 standard reference books, bibliographies, computerized databases, microform publications, archival and oral history collections, pertinent professional associations, and relevant research centers.

The arrangement goes from general to particular, from sources for the study of the concept of religion, including the many academic disciplines which have turned their attention to religion, to information sources on the world's religions, grouped according to traditional geographic areas, with sections on atheism and the occult. A separate section is devoted to Christianity, including chapters on church history and on Christianity's many denominations.

To help locate the resources within the book, the compilers have provided a table of contents and a title, author, organization, and subject index. However, the index is not always accurate and the last section of the book is omitted from the table of contents.

The real drawback to this source guide is that it attempts to cover too much ground. The resources are spread out over so many topics with the result that any one topic risks being inadequately covered. For example, the index only lists six sources of information on religion in Latin America. Five more (inexplicably omitted from the index) can be identified from the table of contents. Moreover, the lack of Spanish- and Portuguese-language sources makes this guide less useful to students of religion in Latin American.

Undoubtedly, other sections are more thoroughly treated and the convenience, especially for reference librarians, of so much information on religion in one handy volume cannot be underestimated. - O.dC.

\section{LANGUAGE}

The Oxford Companion to the English Language. Tom McArthur, ed., Feri McArthur, managing ed. Oxford; New York: Oxford Univ. Pr., 1992. 1,184p. \$45 (ISBN 0-19-214183-X). LC 92-224249.

Editor Tom McArthur states, "Sacred threads run though the world of reference books and one of them bears the colours of Oxford," (Pref.). A onevolume companion to the global language of the late twentieth century is no easy task, and, in the end, the editors found it better to define all that this work would not be: not a gazetteer, not a style or use guide, not a grammar or history, not a linguistic atlas nor a dictionary of slang, phrase, and allusion-though all those elements do appear in the final product. The result, to adapt a phrase from Lewis Carroll, is a portmanteau book, and a handy work for browsing or for consulting on all sorts of questions on the history, dialects, literatures, and curiosities of the English language throughout the world.

Short, signed articles are alphabetically arranged and address twenty-two broad themes: geography (further broken down into Africa, America, Asia, Europe, and Oceania, and from there into individual countries or regions); history (e.g., Royal Society, Anglo-Saxon Chronicles); biography (Marshall McLuhan, Virginia Woolf); name (forms of address, trademark); literature (James Joyce, in- 
tertextuality); style (wit, sexism); education (TESOL, English Language Amendment); grammar (dangling participle, Fowler); writing (uncial, creative writing); speech (Pygmalion, Churchill); reference (Onions, Roget); word (Nonce word, Confusable); usage (barbarism, Doublespeak Award); language (echolalia, American Dialect Society); variety (Gullah, BBC English); media (telephone, headline); and technology (serif, mouse). The main entry for each theme lists all related articles, so that one can read through a series of entries on similar subjects. However, many of the articles fall under several main themes, and the reader may also trace related topics by following crossreferences within the text. Most readers will prefer to browse through the volume, grazing on a richly varied diet which includes items as diverse as rap, The New Yorker, quotation marks, and Lambdacism.

Bibliographical references are included within the text and the volume concludes with a name index. Though much of the information contained in the Oxford Companion to the English Language could be found in dozens of other reference works, not many other one-volume works would have entries for such a wide variety of topics. - B.J.

\section{LITERATURE}

Bassett, John E. Harlem in Review: Critical Reactions to Black American Writers, 1917-1939. Selinsgrove, Pa.: Susquehanna Univ. Pr.; Cranbury, N.J.: Assoc. Univ. Presses, [1992]. 232p. $\$ 36.50$ (ISBN 0-945636-28-8). LC 90-51013.

This is a well-conceived and carefully executed reference work. Its aim is clearly defined: to explore how black and white reviewers treated the aesthetic and political questions raised by black prose and verse writers of the 1920 s and 1930s. It limits itself to literary works and discussions of literature. While primarily a bibliography of book reviews, pertinent scholarly articles and literary criticism are also included.

The book follows a chronological arrangement. The years covered-19171939-are broken down into periods.
Within each period, authors are listed with titles with their respective reviews. The book review section is followed by citations to general criticism and scholarship of that period. Most references have a brief annotation; the book reviews are rated on a spectrum from favorable to unfavorable. A final chapter extends selective coverage to 1944. An introductory essay puts the collection of bibliographic references into context. Since the book lacks a table of contents, the author and critics indexes are essential for name access to the work.-O.dC.

Sajdak, Bruce T. Shakespeare Index: An Annotated Bibliography of Critical Articles on the Plays, 1959-1983. Millwood, N.Y.: Kraus, 1992. 2v. \$302 (ISBN 0527789321). LC 91-28335.

Yes, Virginia, another Shakespeare bibliography. This one is an annotated listing of English-language articles on the plays appearing in reasonably accessible journals arranged by broad subject, and then by publication date.

The second volume is a detailed set of indexes by character, scene, and subject. The characters are listed under the individual plays, so that a student cannot, for instance, simply look up Bianca or Bottom. The subject headings are quite detailed and often seem to consist of keywords from the annotations. For the patient user, this bibliography will have its rewards, but libraries with Champion's The Essential Shakespeare (Suppl. BD26) and the Garland Shakespeare Bibliographies (Suppl. BD261) will want to think twice before investing both the money and the reference librarian's time. - M.C.

\section{ARCHITECTURE}

Gretes, Frances C. Directory of International Periodicals and Newsletters on the Built Environment. 2d ed. New York: Van Nostrand Reinhold, 1992. 442p. \$79.95 (ISBN 0-442-00792-2). LC 91-43506.

This work, which supersedes and considerably expands the original edition published in 1986 (175p.), "was ... prepared primarily to assist professionals 
who are involved in the planning, design, construction, and preservation of the built environment to locate international serially published sources of information relevant to their specific interests," (Introd.). The undeniable growth of interest in architecture and urban form during the mid- to late-1980s, and which continues in the 1990s, spawned "a tremendous outpouring of new periodicals and newsletters dealing with the built environment that has made the process of identifying and locating relevant subscriptions difficult and expensive." This directory lists and describes over 1,600 serial publications currently being produced by architecture schools, professional associations, government agencies, private consultants, and nonprofit organizations in fifty-seven countries, as well as the major publishing companies. Included are titles that contain a substantial number of articles on the built environment with sufficient bibliographic data to be clearly identified. Foreign periodicals selected are those that provide English summaries or are indexed in a published or online source available in the United States.

The directory is arranged in fourteen major categories, including architecture, building types, office practice, interior design, historic preservation, planning, construction, real estate, and the fine and decorative arts. A "User's Guide" describes the arrangement of entries, abbreviations, country codes, international money symbols, and identifies nearly seventy indexing, abstracting, and online full-text database services through which the periodicals can be accessed. Each entry is given full bibliographic and publisher information, including telephone and fax numbers, circulation figures, regular features such as advertising, book reviews, and illustrations, and a brief description of its content, editorial policy, types of articles, language notes, and overall quality. ISSN numbers close out the entry. Especially useful is a note about title changes where they have occurred. The titles that have not been directly examined by the author are indicated by an asterisk. Arrangement is alphabetical by title under the major categories listed above, followed by a separate chapter for the indexing, abstracting, and database services. An alphabetical index to all titles, a geographical index, and a subject index, all with entry numbers, provide the needed additional access points.

Architects, engineers, interior designers, contractors, preservationists, landscape architects, planners, real estate professionals, building product and equipment manufacturers as well as students and librarians who rely on periodical information in these fields will find this directory useful for business and academic applications. Its well-defined scope of the built environment makes it a welcome alternative to the more general periodical directories such as $\mathrm{Ul}$ rich's (Guide AE10) and The Serials Directory (Suppl. AE6). - B.S.-A.

\section{ECONOMICS - PUBLIC FINANCE}

The Handbook of Municipal Bonds and Pub-

lic Finance. Comp. and ed. Robert Lamb, James Leigland, Stephen Rappaport. New York: New York Institute of Finance, 1992. 879p. (ISBN 0-13373960-0). LC 92-26109.

As stated in the introduction, this handbook "is designed to help professionals in a variety of fields understand the most important of the new developments in the municipal securities industry and evaluate the most innovative solutions to emerging public finance problems." New developments and state-of-the-art techniques of the past fifteen years have not been addressed in any single volume until now. The forty-two chapters of this handbook, written by industry specialists, cover such topics as debt management, bonding versus pay-as-you-go decisions, and financial infrastructure improvements. On the market side there are chapters on mutual funds and unit trusts, swaps, and refundings. Current issues and future trends are covered by notable industry journalists. Other contributors are drawn from underwriting, investment banking, rating agencies, economists, academics, attorneys, and market makers.

Cumulatively, the book presents a forward looking, broadly focused treatise 
incorporating several perspectives; it is written for a professional or academic audience. An index and glossary are included. Although there is no general bibliography, authors have added bibliographic footnotes. This title is highly recommended for academic and special libraries serving appropriate clients. - J.C.

\section{LAW-SUPREME COURT}

The Oxford Companion to the Supreme Court of the United States. Kermit L. Hall, ed. in chief. New York: Oxford Univ. Pr., 1992. 1,032p. \$45 (ISBN 0-19505835-6). LC 92-3863.

Johnson, John W. Historic U.S. Court Cases 1690-1990: An Encyclopedia. Garland Reference Library of the Social Sciences, 497; American Law and Society, 2. New York: Garland, 1992. 754p. \$125 (ISBN 0-8240-4430-4). LC 91-40175.

Hot on the heels of the Thomas-Hill hearings and the presidential elections come these two very different works, both of which provide historical, social, and political contexts for current and past court controversies. Aiming to offer "a comprehensive guide to the history and current operation of the Court," the Oxford Companion contains several thousand entries in the familiar alphabetical arrangement. The nearly 300 contributors include noted legal scholars and historians, such as Benno Schmidt and Richard E. Ellis, but the volume's accessible tone will prove as popular in the home as in academic libraries. Entries range in length from a few sentences to several thousand words, and, unlike many recent Oxford Companions, all end with brief bibliographies. Also, some articles are accompanied by black-andwhite illustrations or photographs. Topics covered include biographical sketches on all justices, nominees rejected by the Senate, and other prominent figures in the history of the court; certain key concepts in legal history, such as due process or separation of powers; over 400 individual court cases; broad social and political issues, such as abortion, race and racism, and school prayer; historical periods and events; specialized terminology and phrases; and court architecture, painting, and sculpture. This inclusiveness of coverage will delight the browsing reader with fascinating bits of court lore, such as the historical personages who are portrayed as abstract ideals on the pediment frieze of the 1935 court building. In addition, because the volume devotes special emphasis to "explaining the way in which the justices conduct the day-today operations of the court-its processes, practices, and procedures," (Introd.), readers will find articles on such administrative arcana as the "discuss list" and the "seamstress's room" (for the mending of judicial robes). Many entries include fairly recent information; Justice Thomas is profiled, and the article on abortion covers the ramifications of the Webster decision (1989) as well as anticipating the legal questions raised by the RU-486 pill. Three appendices provide the text of the U.S. Constitution; chronologies of nominations, successions, and retirements; and a section on trivia and traditions of the court. Case and topic indexes conclude the volume.

In contrast, Historic U.S. Court Cases does not attempt to present encyclopedic coverage of the U.S. Supreme Court, but "to serve both the student or lay person interested in learning about important American court cases as well as the legal specialist looking for a convenient repository of useful information, analyses, or references." Eighty legal scholars, journalists, historians, and political scientists have contributed 171 essays which range in length from 1,000 to 5,000 words. The essays, which cover issues and cases that have come before state, federal, and even colonial courts, are arranged within six chapters: crime and criminal law; government organizations, power, and procedure; economics and the law; race and gender in American law; civil liberties; and law in critical periods in American history. Short bibliographies follow each essay. Because of the topical arrangement and linking introductory essays, Historic U.S. Court Cases may also serve as a textbook for 
constitutional history class. Also, reference librarians will find that they need to make frequent use of the case and name/subject indexes to locate all the materials on particular issues. Students will appreciate a number of recent, or recently controversial, topics addressed in this volume, including the Pentagon papers, the Bakke case, the rights of migrant workers, and Native American land claims.

Although the bicentennials of the Constitution and the Bill of Rights in 1987 and 1989 have produced a spate of reference works on constitutional and court history, all libraries will want to own the convenient and complete Oxford Companion to the Supreme Court. Many academic libraries may also want to acquire Historic U.S. Court Cases for their circulating collection, if not for reference.-B.J.

\section{AREA STUDIES}

\section{Latin America and the Caribbean: A Critical}

Guide to Research Sources. Paula H. Covington, ed. Bibliographies and Indexes in Latin American and Caribbean Studies, 2. Westport, Conn.: Greenwood, 1992. 924p. \$115 (ISBN 0-313-26403-1). LC 91-34622.

Latin America and the Caribbean is a multidisciplinary research guide with annotated bibliographies and essays which gives "an overview of recent trends in scholarship in a given discipline, the structure of the field and its literature," (Introd.). Essays that summarize the achievements and preoccupations of various fields, mainly since 1960, are copiously footnoted and intended to assist students new to Latin American studies and scholars who are engaged in interdisciplinary research. The new bibliography covers the humanities and social sciences from architecture to women's studies, with an emphasis on history, literature, and the performing arts.

Within a subject, books and periodicals are cited by country. The general bibliography section is subdivided by genre, e.g., book reviews, bibliographies of bibliographies, national and trade bibliographies, biographies, and so forth. A separate chapter deals with computerized databases, giving an overview of Latin American files in such major database systems as Dialog, BRS, Wilsonline, Nexis and Questel. An area not yet explored is the Internet connection that enables researchers, especially those affiliated with universities in the United States, to consult databases in remote domestic and foreign sites.

One advantage of this guide is its subject-oriented approach. An earlier guide, Latin American Studies: A Basic Guide to Sources, 2d. ed., ed. Robert A. McNeil (Suppl. DB94), with many of the same contributors, adopted a format approach. Sources were listed by type of publication, such as national bibliographies, dissertations, and so forth. For students and scholars, a subject approach is preferred because it is easier to use. The book includes author, title, and subject indexes. - J.S.

\section{RUSSIA AND THE SOVIET UNION}

Metzger, Wolfgang. Bibliographie deutschsprachiger Sowjetunion-Reiseberichte, -Reportagen, und -Bildbande, 19171990. Wiesbaden: Harrassowitz, [1991]. 445p. 168DM (ISBN 3-447-03131-X). LC 92-101100.

Travel and memoir literature has long been a key source for the study of Russia, a country of proverbial mystery to its Western neighbors. If anything, this has been even more true of the Soviet period as official controls over the flow of information and international hostilities have combined not only to maintain but even to increase that country's remoteness to outsiders. At the same time, as Soviet studies mature, scholars are becoming increasingly aware of the need to come to grips with the peculiar ways in which Western states and societies perceived the Great Power in the East.

Both these problems are addressed by this new bibliography of more than 5,000 books, pamphlets, and articles. Covering the period from 1917 to 1990 , it attempts to bring together a fairly comprehensive listing of German-language travel accounts, journalistic treatments, and pictorial works that deal 
with the Soviet Union with a more selective listing of magazine and newspaper guides, autobiographical and other works that serve to concretize the image of the Soviet Union for the German-reading public. An effort has been made to include Soviet publications as well, so that a wide range of viewpoints, from officially self-apologetic to overtly hostile, are represented.

The entries are arranged by year, enabling the reader to trace something of the history of the Germans' view of Soviet life. Full bibliographic information is provided, but no annotations other than an indication of the subject matter of an item not explicitly indicated by the title itself. An index to authors and mainentry titles provides additional control, but the lack of a subject index to such a large collection of titles is keenly felt.

The criteria for inclusion are also somewhat unclear, perhaps reflecting the necessarily vague boundaries of the subject matter. One does not find, for example, Gustaw Herling-Grudzinski's Welt olne Erbarmen or Ante Ciliga's Im Land der verwirrenden Lüge, which are key eyewitness accounts of the Gulag from two foreign prisoners. Likewise, while a variety of Soviet memoirs and autobiographies are included, such an important one as Trotsky's is not.

Regardless of these shortcomings, this is clearly an important addition to the bibliography of Soviet studies, far more comprehensive in its scope than any work proceeding it. One can only hope that, with the end of the Soviet era, we will see analogous attempts to come to terms with the literature in other languages as well. - R.H.S

Schmidt, Christoph. Ausgewählte Bibliographien und Bibliothekskataloge zur russischen Sozialgeschichte. Wiesbaden: Harrassowitz, 1989. 108p. 49.80DM (ISBN 3-447-02957-9). LC 90-151713.

Although published three years ago, this concise and useful guide to bibliographies relevant to the study of Russian social history from the peasant emancipation to the revolutions of 1917 does not appear to have been widely reviewed and thus still seems worthy of mention here. An admirable ten-page introduction manages to provide the reader with a fascinating and informative overview of key developments in Russian book publishing and bibliography at the turn of the century, bringing to life such leading figures as A. D. Toropov, D. V. Ul'ianinskii, V. I. Mezhov, and A. V. Mez'er while placing their careers in a broader historical context and providing a substantial list of citations to further literature on the subject. It is followed in the body itself by a closer examination of seventyseven major bibliographies or catalogs, all but seven of them published before 1936, and most of them published before 1916. While diverse in character, ranging from bookseller catalogs to reader's advisers to genuine subject bibliographies, and from the catalogs of key private collections of institutional libraries to the lists of publications of government bodies, the works collectively offer a key to a host of subjects. These subjects include the major social classes and groups, economic issues, local history, minorities such as Germans, Jews, and Gypsies, and such social problems as prostitution, alcoholism, and crime.

Arranged alphabetically, each entry includes a full bibliographic citation, a list of chapter headings, and unusually substantive annotations on the significance of the particular work as well as its arrangement. A subject index provides quick access to the appropriate title or titles. Naturally, such a brief list can only scratch the surface of the rich bibliographic literature on the subject (and the author has explicitly excluded some of the more comprehensive periodical titles from his survey). At the same time, however, its conciseness is a virtue, offering invaluable guidance to the researcher at the beginning of his or her undertaking. It seems well designed, too, as a potential tool for measuring the strength of a library's collection in this field. It clearly belongs in any reference collection supporting advanced studies of Russian history.-R.H.S. 


\section{WOMEN'S STUDIES}

Fischer, Gayle V. Journal of Women's History Guide to Periodical Literature. Bloomington, Ind.: Indiana Univ. Pr., 1992. 512p. $\$ 39.95$ (ISBN 0-253-322197). LC 91-28470.

This bibliography of English-language material lists some 5,500 citations to journal articles published from 1980 through 1990, arranged in forty broad chapters, "Africa" to "Work." There are no subject or author indexes, although most entries are cross-listed under more than one subject. The bibliography is still somewhat difficult to use, however, because there are no cross-references. A reader looking for articles on nineteenth-century infanticide might find the "infanticide" section of the "Birth Control" chapter, but might not realize that there are additional articles in the "female criminality" and "reproductive rights and illegitimacy" sections of the "Law/Crime" chapter, and in the "infant mortality" section of the "Family" chapter. Although most of the articles in the bibliography could easily be found in America: History and Life or Historical Abstracts, there are some unique citations to articles in newsletters. This is recommended for libraries with large women's studies collections, or for libraries without access to the periodical indexes mentioned above.-S.S.

Nemec Ignashev, Diane, and Sarah Krive. Women and Writing in Russia and the USSR: A Bibliography of English-language Sources. Garland Reference Library of the Humanities, 1280. New York: Garland, 1992. 328p. \$51 (ISBN 0-8240-3647-6). LC 92-9246.

Women and Writing in Russia and the $U S S R$ is a fine bibliography which will please many undergraduate and graduate students, even though it only includes writings in English. It is arranged in four sections:

- Primary Sources: Creative Writing and Personal Documents" lists translations of fiction, and subjective nonfiction alphabetically by woman author.

- "Biographical and Critical Sources" includes criticism of individual women artists, studies of women in specific time periods, and studies of the representations of women in the art of both men and women.

- "Supplementary Sources on Women and Women's Experience" covers works about education, health and medicine, law, military, mothering (including childbearing, childrearing, family, and marriage), national identity, politics, prison and labor camps, religion and spirituality, rural communities, work, interviews, status of women, yearbooks and statistical reports.

- "Bibliographies" cites twenty-four bibliographies. Coverage extends from the nineteenth century through 1990, with some entries from 1991. Includes a personal name index.-S.S.

\section{Annotated Index of Medieval Women. Anne}

Echols and Marty Williams, eds. New York: Markus Wiener, 1992. 635p. \$69.95 (ISBN 9-910129-27-4). LC 90-39810.

This index provides brief biographies with citations to primary and secondary sources for some 1,300 medieval women living between 769 and 1500 . Women are listed alphabetically by first names, and forms of the same name are interfiled (e.g., Marie of Anjou, Mary of Antioch, Maria of Aragon...). Tables at the end of the volume list women by country, date, surname or region of origin, and biographical categories, which are taken to include professions (abbesses, alewives, and apothecaries), subjects (abduction, adultery, and antinomian heresies) and political roles (negotiators, pawns, and squabbles). European and Byzantine women figure most prominently in this index, although there are a few entries for women in China, Israel, and Lebanon. This is the sort of index that would be very appealing to undergraduates and could also be useful to graduate students.-S.S.

\section{CHRISTOPHER COLUMBUS}

When the Organization of American States established a library of interAmerican affairs in 1902, the representatives of member states apparently had no quibble about naming the library "the 
Columbus Memorial Library." Almost everything relating to Columbus has become a subject of dispute lately, from the rejection of the Eurocentric concept of the "discovery of the New World" to the whereabouts of his mortal remains (no less than three locations: Havana, Santo Domingo, and Seville). Those interested in controversies surrounding the 500th anniversary of Columbus' voyage to America will welcome some new reference sources for rethinking the significance of his adventure. Several updated Columbus bibliographies and dictionaries have appeared, although not as many as the publications produced at the French Revolution's 200th anniversary. The following is a brief overview of recent reference books of a general nature, excluding collection-specific bibliographies.-J.S.

Conti, Simonetta. Bibliografia Colombiana, 1793-1990. Genova: Cassa di Risparmio di Genova e Imperia, [1990]. xxxviii, 920p. LC 91-201085.

An update of the bibliography published in 1986, Un Secolo di Bibliografia Colombiana, 1889-1985 (Genova: Cassa di Risparmio di Genova e Imperia, 1986. 360 p.), this edition offers 8,383 entries alphabetically arranged by author with an index of journals, author index, and a topical index. An appendix for items $8,384-8,409$ is not indexed. The author index is somewhat redundant because the bibliography is arranged alphabetically. The topical index could have used more subdivisions of topics; as it is, item numbers can fill two-thirds of a page under a single subject heading. The bibliography and the journal listing, though, are a mine of information even if difficult to retrieve. Literary works by such people as Lamartine and Zweig are cited. This book is intended to fill the gap left by recent bibliographies that cover specific library collections or time periods.

Provost, Foster. Columbus: An Annotated Guide to the Scholarship on His Life and Writings, 1750-1988. Detroit: Publ. for the John Carter Brown Library, Brown
University, by Omnigraphics, 1991. xxxii, 225p. \$54 (ISBN 1-55888-157-3). LC 90-27572.

Provost's bibliography offers an extensive international survey of printed primary sources and works of historiography, biography, politics, society, religion, natural science, navigation and iconography, dating from 1750 to 1988 . All 780 entries for books and articles are annotated. It is indexed by author/editor, proper name, and topic.

Columbus Dictionary. Detroit: Omnigraphics, 1991. 142p. \$54 (ISBN 1-55888-158-1). LC 91-29120.

Provost's companion volume gives concise accounts of people, places, events, and ideas with a major emphasis on personal and place names. Each entry has a bibliographic note and a concluding bibliography of English-language sources, especially works of Samuel Eliot Morison on which the Dictionary is based. The book is not illustrated.

Barceló F. de la Mora, José Luis and Barceló Mezquita, José Luis. Summa Colombina: Diccionario Enciclopédico de Colón. [Madrid]:Sociedad Estatal Quinto Centenario, Progensa, 1990. 512p. il., maps. 3,500 pta. (ISBN 84-86505-33-X). LC 91-175649.

In this Spanish encyclopedia with numerous black and white illustrations, the topics range from mythology of seafaring to historical documents, with a number of entries for personal and place names. The appendixes include chronological tables, a list of the crew members of the three ships of the first voyage, detailed descriptions of the ships, a chronological list of commemorative postage stamps honoring Columbus, maps, and documents.

Although each article is not documented, this volume contains a number of entries not found in Provost's dictionary, as well as the texts of historical documents and pictures of historical maps.

The Christopher Columbus Encyclopedia. Silvio A. Bedini, ed. New York: Simon \& 
Schuster, 1992. 2v. (xxii, 787p.) il., maps. \$175 (ISBN 0-13-142662-1). LC 90-29253.

The encyclopedia offers signed articles by international contributors, each accompanied by a short bibliography, often with line drawings and monochrome photographs. This is perhaps the best among these three encyclopedias for giving the broad historical background and context in which Columbus' discoveries were made. For example, the article titled "Religion" has two parts: one presenting European traditions and the other on Amerindian traditions. This is more like an encyclopedia of the age of discoveries, with a comprehensive survey of the society, encompassing such varied aspects as agriculture, flora and fauna, science and technology, Muslims and Jews, trade and economic institutions, art and architecture, equipment, clothing and rations on board Columbus' ships, an overview of Columbus memorabilia, and documentary sources in museums and archives. It includes a subject index.

\section{NEW EDITIONS AND SUPPLEMENTS}

Kenneth Kister's Best Dictionaries for Adults and Young People (Phoenix, Ariz.: Oryx, 1992. 438p. $\$ 39.50$ ) is a muchneeded revision and updating of the introduction and dictionary profiles of the "Adult" and "School and Children's Dictionaries" portions of his Dictionary Buying Guide (Guide AD2). The compiler has made a determined effort to describe both the print and electronic formats of the dictionaries under review. The appendixes now include a listing of dictionary and language associations, much expanded bibliographies, and a longer directory of dictionary publishers and distributors.

Kister gives a fascinating discussion of the first two editions of the American Heritage Dictionary of the English Language (1st ed., 1969; 2d ed., 1982; Guide AD13). The third edition (Boston: Houghton Mifflin, 1992. 2,140p. \$38.95) seems to hark back to the first edition in its appearance, size, and number of il- lustrations. The number of words covered is about the same as in the second edition $(200,000)$ though the editor points out there are 16,000 new words and meaings and more illustrative quotations. Nine hundred synonym paragraphs offer very detailed distinctions between words. Usage notes remain a big feature in this dictionary. Revised too is the appendix of Indo-Aryan roots.

The BBC English Dictionary has been updated to reflect usage and punctuation as of May 1992 (London: HarperCollins, 1992. xxiv, 1,374p. £14.95; 2 d ed. 1983, Guide AD77). The BBC developed a database, the "Bank of English," consisting of all BBC broadcasts made throughout 1988-1992 and 10 million words contributed by National Public Radio in Washington from their 1991 broadcasts. This corpus provided the entries, definitions, pronunciations, and preferred usage for people, places, and events to provide background information. Also included are about one thousand entries.

The IBN: Index bio-bibliographicus notorum hominum by Jean-Pierre Lobies (Guide AJ18, Suppl. AJ6) usually includes Part B, the list of source works added, as front matter in many of the volumes of Part C. This time, however, an unpaged Part B is issued as a separate volume giving entries 5146-6215 for new biographical works (Osnabrück: Biblio, 1992).

Volume 2 of American Nursing: A Biographical Dictionary, comp. Vern Bullough, Lilli Sentz, and Alice P. Stern, (Garland Reference Library of the Social Sciences 684; New York: Garland, 1992. 389 p. \$95) adds some 214 sketches to the 177 nurses in volume 1 (Suppl. EK94). This time the cutoff date is 1915 . The indexesby decade of birth, nursing school attended, area of special interest, state and country of birth-cover both volumes.

Pierre Conlon for his Le siècle de lumières: bibliographie chronologique (Guide AA751, Suppl. AA113) has produced some housekeeping volumes: tome IX (145p.) is a supplement to the volumes covering 1716-1760 for works omitted, corrections, revised entries; tome $\mathrm{X}$ (493p.) is an alphabetical list of titles so far included. The referral number for 
this last-named index is made up of the last two digits of the year and the assigned item number within the year (Genève: Droz, 1992).

Deutsche literarische Zeitschriften, 1945 1970, comp. Barnard Fischer and Thomas Dietzel (Munich, New York: Saur, 1992. 4v. 680DM), is a continuation of the indispensable bibliography of nineteenth- and twentieth-century German literary periodicals compiled by Alfred Estermann (Suppl. AE36) and Thomas Dietzel (Suppl. AE35). Based on the holdings of the Deutsche Literaturarchiv in Marbach, the 1,331 alphabetically arranged titles include literary, theatrical, and general-interest publications. The extraordinarily detailed listings provide variant titles, places and dates of publication, a detailed collation, editors, major contributors, holdings in some 200 European libraries, and often excerpts from the introduction to the first issue or the prospectus. Indexed by editor, contributor, publisher, place of publication and by broad subject.-M.C.

Those cumulative volumes of Suomen kirjallisuus for 1967-1971 (Helsinki: Univ. Library, $1992.3 \mathrm{v}$.) bring back categories of materials that have been published separately (see Guide AA740 for an explanation). The alphabetical listing for books, 1967-71, vols. 1-2, presents books published in Finland, and books in Finnish or books by a Finnish author or translator published abroad. Monographic series are included in the books section. Volume 3 contains a list of serials, mostly annuals since journals are covered by Bibliography of Finnish Periodicals, 1956-1977 compiled by Marketta Takkala (Helsinki, 1986). Publications of the University Library, Helsingin yliopiston kirjaston julkaisuja, 48. 632p.) Also in volume 3 are lists of printed maps and sheet music. All parts are indexed by a classed list.

The Music Catalog (Washington: Library of Congress, 1991- . Quarterly. \$100) is the new title for NUCMusic Books, Books on Music and Sound Recordings (Guide BH92). The older title was available in both microfiche and paper, the successor is only on microfiche. The Music Catalog is quarterly to cumulate annually.
The Introduction to Scholarship in Modern Language and Literature, ed. Joseph Gibaldi (New York: Modern Language Assn., 1992. 377p. \$37; 1st ed. 1981) is a collection of bibliographical essays by scholars introducing students to the "myriad activities pursued by linguistic and literary scholars" (Pref.) such as "Cultural studies," "Ethnics and minorities," "Textual scholarship." See also the epilogue, "The scholar in society" by Gerald Graff.

Another very useful revision is MaryClaire van Leunen's book of advice for citing works, for handling quotations, and for composing footnotes and bibliographies: A Handbook for Scholars (New York: Oxford Univ. Pr., 1992.348p. \$12.95; 1st ed. 1978). In fact there is an appendix devoted to citing U.S. federal documents. The other appendix deals with the curriculum vitae, what elements to include, how to present the information.

Dorothy Eagle died before she could complete the revision of her Oxford Illustrated Literary Guide to Great Britain and Ireland (1981, Guide BD568), which is itself a revised and illustrated edition of the Oxford Literary Guide to the British Isles (1977). Meic Stephens has completed the work (Oxford: Oxford Univ. Pr., 1992. $322 \mathrm{p}$. \$45) with the addition of many new authors (137) and places (105), especially expanding coverage of Scotland, Wales, and Ireland. Still heavily illustrated with drawings and photographs, the work ends with thirteen regional maps.

BNTL: Bibliografie van de nederlandse taal- en literatuur-wetenschap indexes books and articles on literature and language published in Holland. Begun in 1975 , it is an annual with a classed arrangement and with author and title indexes. This year the compilers have issued a retrospective volume covering the years 1940-1945 (s'Gravenhage: Stechting Bibliographia Neerlandica).

Edna Coll has issued volume 5 of the Indice informativo de la novella hispanoamericana (Rio Pedras: Ed. Univ. Puerto Rico, 1992. 541p.) this one covering the Altiplano: Bolivia, Ecuador, and Peru. The arrangement is the same as in the earlier volumes (Guide BD1213): for each 
country, a general section is followed by authors in an alphabetical list with citations for novels and critical and biographical works for each. Many of the entries have biographical notes.

For Mexico, David Foster has enlarged his Mexican Literature: A Bibliography of Secondary Sources (Metuchen, N.J.: Scarecrow, 1992. 686p. \$67.50; 1st ed., 1981, Guide BD1242) to include 80 authors both colonial and twentieth century. The first edition treated only twentieth-century authors, index of critics.

Warren Walker has been most assiduous in his care for the short story. Now he has produced an index to the third edition with its five supplements, 19611991 (Guide BD254) of Twentieth-century Short Story Explication (Hamden, Conn.: Shoe String, 1992. 254p.). Arranged by literary author and short story, a citation indicates the volume and page of the bibliographic reference to the explication.

The second edition of Gerald Bordman's American Musical Theatre: AChronicle (New York: Oxford Univ. Pr., 1992. 821p. \$49.95; 1st ed. 1978, Guide BH247) extends coverage to the 1989-90 season. Added too are "turn-of-the-century musicals that toured from city to city without every playing first-class houses" (Pref.). These are in an appendix along with "musicals that did play first-class houses but which were overlooked originally." Indexed are shows and sources, songs, and people (including nine theaters).

The Encyclopedia of Educational Research with Marvin C. Alkin as editor-in- chief (New York: Macmillan, 1992. 4v. $\$ 330$; 5 th ed. 1982, Guide CB143) strives to provide a "valuable record of the conception of education in the early 1990s" (Pref.). The articles are written by scholars and most of them have been revised. New areas of concentration discuss "societal issues of the time that affect education: pregnant and parenting teenagers, prevention intervention, AIDs education." There is an additional emphasis on the teachers themselves. The appendix covers "doing library research in education."

Wahib Nasrallah has revised his United States Corporation History (New York: Garland, 1991. 522p. \$67; 1st ed. 1987, Guide CH141); it now extends the period of coverage from 1965 to 1990; twenty-five collective histories are cited in an appendix.

Volumes 1-8 of A List of Geographical Atlases in the Library of Congress, comp. Clara Egli LeGear (Guide CL286), is a major catalog of a collection amassed over a century. Now Ms. LeGear has issued A Comprehensive Author List to Volumes 1-8 (Washington, D.C.: GPO, 1992. 289p. \$19).

Jacques Barzun and Henry Graff have revised The Modern Researcher, 5th ed. (New York: Harcourt, 1992. 409p. \$); 4th ed., 1985, Guide DA4). It is still a research manual with much illustrative material, but now the uses of the computer are covered. As the authors note: "When our First Edition was published, the ballpoint pen was a recent invention. ... In the present edition we discuss laptop and other computers" (Pref.). 